\title{
The Relationship between Supply Chain Management Practices and Supply Chain Performance in Saudi Arabian Firms
}

\author{
Yaser Y. Alahmad \\ College of Business Administration, Albaha University, Albaha, KSA \\ Email: yalahmad@bu.edu.sa
}

How to cite this paper: Alahmad, Y. Y (2021). The Relationship between Supply Chain Management Practices and Supply Chain Performance in Saudi Arabian Firms. American Journal of Industrial and Business Management, 11, 42-59.

https://doi.org/10.4236/ajibm.2021.111004

Received: December 9, 2020

Accepted: January 16, 2021

Published: January 19, 2021

Copyright $\odot 2021$ by author(s) and Scientific Research Publishing Inc. This work is licensed under the Creative Commons Attribution International License (CC BY 4.0).

http://creativecommons.org/licenses/by/4.0/

\begin{abstract}
The purpose of this study was to investigate the relationship between supply chain management practices (SCMPs) and supply chain performance (SC performance) within different industries in the Kingdom of Saudi Arabia. An empirical study was conducted on a sample of 196 firms; information was collected from the supply chain managers and those in top management in different industries in the Kingdom of Saudi Arabia. In addition to a series of interviews conducted with managers of the supply chains, a theoretical model was developed depicting the relationship between SCMPs and supply chain performance (SC performance). This model was also tested using multiple regression analysis. The research suggests that SCMPs, including supply chain planning (SC planning), level of information sharing (IS), customer relationship management (CRM), and supplier relationship management (SRM) are all positively related to SC performance. Additionally, SC performance is positively related to FFP. The research employed perceptual performance measures to gauge return on investment, revenue, and sales. Future studies could use actual numbers to better quantify the benefits within this context.
\end{abstract}

\section{Keywords}

Supply Chain Management Practices, Supply Chain Performance, Supply Chain Planning, Level of Information Sharing, Information Quality, Risk and Reward Sharing, Customer Relationship Management, Supplier Relationship Management

\section{Introduction}

The present business environment is a competitive one, but such competitive 
challenges can be addressed through effective supply chain management (SCM). As defined by the Council of Supply Chain Management Professionals (CSCMP), SCM refers to the planning and management of all activities surrounding sourcing, procurement, and conversion; logistics planning and management; and the coordination and collaboration that occur among supply chain partners. Saudi companies face challenges in the global market in regard to their competitive edge, and these challenges can naturally affect the performance of a company. Therefore, to ensure sustainability, Saudi companies need to maintain a competitive advantage. One strategy a company can use to sustain a competitive advantage is to maintain effective supply chain SCM. SCM is theorized to consist of individual functional entities that perform their duties in such a way as to provide resources and information to all parts of the supply chain (SC), thereby allowing management to achieve their goals while also maintaining a smooth flow of all parts of the chain Lau \& Lee (2000). To this end, SCM is made up of a variety of practices that can mutually raise the performance of and benefit all supply chain members, including suppliers, manufacturers, distributors, and customers (Chopra \& Meindl, 2001). Academic researchers and business managers alike have started paying increased attention to supply chain management practices (SCMPs) (Croom, Romano, \& Giannakis, 2000; Li, Rao, Ragu-Nathan, \& Ragu-Nathan, 2005; Tan, Kannan, \& Handfield, 1998). As a result, many firms now consider SCMPs to be one of the most important aspects of developing and maintaining a competitive advantage in the marketplace (Jones, 1998; Li et al., 2005). Therefore, while it is recognized that SCMPs have an effect on a firm, it is necessary to more specifically measure this impact on the firm's performance (Green, McGaughey, \& Casey, 2006). From interviews conducted with different supply chain managers and purchasing managers, a problem exists in Saudi companies in that top management does not know the impact of different practices on SC performance, nor do they clearly know which practices have the most impact on SC performance. Despite the increased attention on SCMPs, there is still insufficient research on SCMPs in emerging countries, such as Saudi Arabia. Furthermore, there also been conflicting findings in regards to the impact of different practices on firm performance; for example, Gandhi, Shaikh, \& Sheorey (2017) found that customer relationship management (CRM) has a positive impact on firm performance, but Sundram, Ibrahim, \& Govindaraju (2011), in their study of SCMPs in the electronics industry in Malaysia, found that CRM did not affect positively on the firm's performance.

The purpose of this current research was to investigate the relationship between SCMPs and supply chain performance (SC performance) in Saudi firms. Additionally, the results of this study will be able to help managers and other decision-makers take advantage of efficient SCMPs by assisting them in understanding the potential effects of each practice. SCMPs are defined as the set of activities that an organization uses to boost effective management of its supply 
chain (Li et al., 2005). SCMPs are proposed to be a multi-dimensional concept encompassing both the supplier and customer sides. This study has taken items from SC literature and has tested them empirically by using data collected from Saudi firms in a variety of industries; with this information, six supply chain practices are discussed: supply chain planning (SC planning), risk and reward sharing (RR sharing), information sharing (IS), information quality (IQ), supplier relationship management (SRM), and customer relationship management (CRM).

The study contribution is in conceptualizing the complementing impacts of SC planning, RR sharing, IS, IQ, SRM, and CRM practices on SC performance. It makes two contributions. First, to the best of my knowledge, this study is the first research to investigate the relationship between SCMPs and SC performance in the context of Saudi firms.

Second, for SCM practitioners the study shows that implementing the SCMPs are effective ways to improve SC performance. Additionally, it offers supply chain managers overseeing a supply chain advice for what type of practices they should implement.

The current study is organized as follows: section two synthesizes the relevant literature review and hypothesis development. Section three follows with the research design and methodology. Section four discusses the results and hypotheses findings. Lastly, section five discusses the managerial implications, research limitations, and future research.

\section{Literature Review and Hypothesis Development}

\subsection{Literature Review}

SCMPs are a set of practices that integrate all levels of the SC, such as suppliers, manufacturers, distributors, and customers, in order to improve SC performance and FFP (Barros, 2006; Koh, Demirbag, Bayraktar, Tatoglu, \& Zaim, 2007). Min \& Mentzer (2004) identified the concept of SCMPs as that of including an agreed-upon vision and goals, IS, RR sharing, cooperation, process integration, long-term relationships, and agreed-upon supply chain leadership. (Zhou \& Benton Jr., 2007) went further and investigated the integration of IS, SC planning, just-in-time (JIT) production, and delivery practice in supply chain management. Sundram et al. (2011) examined the relationship between various SCMPs, including supplier strategic partnership, customer relationship, IS, IQ, postponement, agreed-upon vision and goals, RR sharing, and SC performance. Chong, Chan, Ooi, \& Sim (2011) empirically tested a framework that identifies the relationships between SCMPs in Malaysian manufacturing and service firms, practices including those of strategic supplier partnerships, customer relationships, IS, information technology, training, internal operations, operational performance, and innovation performance. Sukati, Hamid, \& Baharun (2013) analyzed the data to find the connection between business performance and the implementation of SCMPs which included internal firm relationships, firm-customer 
relationships, and firm-supplier relationships. To study the causal relationship between SC performance and FFP, Barber, Garza-Reyes, Kumar, \& Abdi (2017) developed seven dimensions, which include strategic supplier partnership, IS, IQ, CRM, internal lean practices, postponement, and total quality management. Saragih, Tarigan, Pratama, Wardati, \& Silalahi (2020) examined and explained the relationship between operational performance and ten SCMPs including IS and visits to the sites, supplier relationship, inventory management, product development, agility, implementing quality, integration of logistics, transportation, and purchasing activities with the process of manufacturing. The findings of Saragih et al. (2020) showed that sustainable operational performance could be achieved through SCM. Yanya \& Mahamat (2020) investigated the influence of SCMPs including logistics integration and organizational learning in SCM perspective to achieve competitive advantages and improve a firm performance. The study was performed on the pharmaceutical industry of Thailand. The findings of this study showed positive significant relationship between organizational learning and competitive advantage, logistics integration, and competitive advantages. Kumar \& Kushwaha (2018) provided empirical insights of the relationship between different supply chain management practices (CRM, information technology, information quality) and operational performance of the fair price shops in India. The study affords that three dimensions of SCM practices have a significant and positive relationship with the operational performance.

Beside the impact of SCMPs on SC performance, SCMPs have a great impact on customer satisfaction and loyalty, supply chain pricing, and contract design in SC. For instance, Prathiba (2020) studied the effects of supplier affiliation, customer affiliation, and knowledge sharing on customer satisfaction and loyalty. The study concluded that SCMPs enhance customer satisfaction and loyalty. Chen, Peng, Liu, \& Zhao (2017) analyzed the pricing and effort decisions of a SC. The finding suggests that customers are a less possible benefit from a power retailer. When the manufacturer and the retailer have equal bargaining power, customers perhaps benefit from the SC. Xiao, Chen, Xie, \& Wang (2020) studied the interactive impacts of retailer's fairness and manufacturer's overconfidence on best possible contract design in a SC. They concluded that the SC achieves the highest profit under the revenue-sharing contract. Table 1 shows how the literature review provides the theoretical foundation for this study.

\subsection{Hypothesis Development}

In this section, we discuss the relationship between SC planning, RR sharing, IS, IQ, SRM, CRM, and SC performance, as well as the relationship between SC Performance and FFP. Figure 1 illustrates the theoretical framework developed for this research. This framework allows for the understanding of the antecedents and consequences of SC performance as described by the relationships between SCMPs, SC performance, and FFP. This framework is underscored by the rationale that implemented SCMPs. Such a framework will lead to an im- 
provement in the SC performance and, thus, to the improvement of FFP. Specifically, this framework shows that SCMPs have an indirect effect on SC performance (Li, Ragu-Nathan, Ragu-Nathan, \& Rao, 2006). The SCMPs are conceptualized through six constructs, as seen in Figure 1.

Table 1. Literature of SCMPs.

\begin{tabular}{|c|c|c|c|c|c|c|}
\hline \multirow{2}{*}{ Author/s } & \multicolumn{6}{|c|}{ SCMPs } \\
\hline & SC Planning & RR Sharing & IS & IQ & SRM & CRM \\
\hline (Min \& Mentzer, 2004) & & $\mathrm{x}$ & $\mathrm{x}$ & & & \\
\hline (Zhou \& Benton Jr., 2007) & $\mathrm{x}$ & & & & & \\
\hline (Sundram et al., 2011) & & $\mathrm{x}$ & $\mathrm{x}$ & $\mathrm{x}$ & $\mathrm{x}$ & $\mathrm{x}$ \\
\hline (Chong et al., 2011) & & & $\mathrm{x}$ & & $\mathrm{x}$ & $\mathrm{x}$ \\
\hline (Cook, Heiser, \& Sengupta, 2011) & $\mathrm{x}$ & & $\mathrm{x}$ & & $\mathrm{x}$ & \\
\hline (de Souza Miguel \& Brito, 2011) & & & $\mathrm{x}$ & & & \\
\hline (Sukati, Hamid, Baharun, Yusoff, \& Anuar, 2012) & & & $\mathrm{x}$ & & $\mathrm{x}$ & $\mathrm{x}$ \\
\hline (Adebayo, 2012) & & & $\mathrm{x}$ & & $\mathrm{x}$ & $\mathrm{x}$ \\
\hline (Gharakhani, Mavi, \& Hamidi, 2012) & & & $\mathrm{x}$ & & $\mathrm{x}$ & $\mathrm{x}$ \\
\hline (Gawankar, Kamble, \& Verma, 2013b) & & & $\mathrm{x}$ & & $\mathrm{x}$ & $\mathrm{x}$ \\
\hline (Sukati et al., 2013) & & & & & $\mathrm{x}$ & $\mathrm{x}$ \\
\hline (Teller, Kotzab, Grant, \& Holweg, 2016) & & & & & & $\mathrm{x}$ \\
\hline (Gandhi et al., 2017) & & & $\mathrm{x}$ & & $\mathrm{x}$ & $\mathrm{x}$ \\
\hline (Barber et al., 2017) & & & $\mathrm{x}$ & $\mathrm{x}$ & $\mathrm{x}$ & $\mathrm{x}$ \\
\hline (Shetty, 2019) & & & & & & $\mathrm{x}$ \\
\hline (Saragih et al., 2020) & & & $\mathrm{x}$ & & $\mathrm{x}$ & \\
\hline (Kumar \& Kushwaha, 2018) & & & & $\mathrm{x}$ & & $\mathrm{x}$ \\
\hline (Prathiba, 2020) & & & $\mathrm{x}$ & & $\mathrm{x}$ & $\mathrm{x}$ \\
\hline
\end{tabular}

$\mathrm{x}$ : means the topic was discussed in the article.

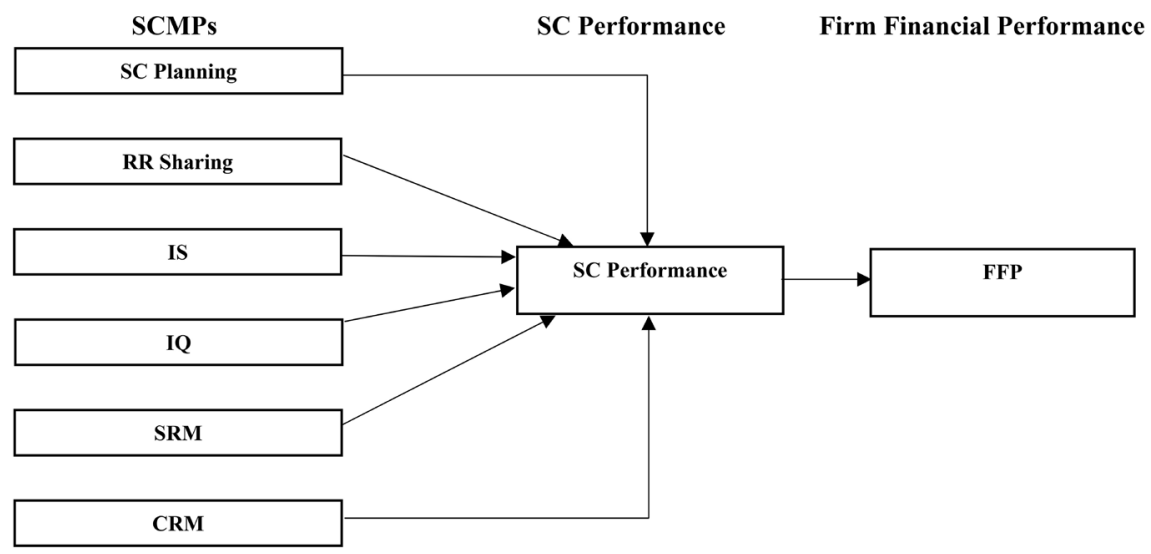

Figure 1. Research framework. 


\subsubsection{SC Planning}

The practices of SC planning are used to process information from suppliers, customers, and internal operations, in turn contributing to the calculation of future demand wherein the various functions between a firm, its suppliers, and customers become synchronized. The importance of predicting the supply chain demand is well-documented (Aviv, 2001; Lee, Padmanabhan, \& Whang, 1997), as this forecast can affect different factors of SC performance. The relationship between the predicted SC demand and delivery performance has been well researched (Cook \& Rogowski, 1996; Krajewski \& Wei, 2001). Additionally, since department alignment is necessary for achieving a firm's objectives, inter-functional coordination and alignment within the firm is also important (Hodge, Anthony, \& Gale, 1996; Womack, Jones, \& Roos, 1990). Thus, the following hypothesis has been created:

H1: SC planning has a positive impact on SC performance.

\subsubsection{Risk and Reward Sharing (RR Sharing)}

$\mathrm{RR}$ sharing refers to a mutual sharing of both the risk and reward elements among supply chain partners (Bowersox, Closs, \& Stank, 1999; Min \& Mentzer, 2004; Sundram et al., 2011). The three mutual dimensions of risk include the likelihood of a certain outcome occurring, the consequences, and the overall cause of the outcome (Jüttner, 2005). RR sharing between partners of the supply chain assists the partners in divvying up the risk and reward levels for aspects of technology, customers, and market-focused initiatives (Hall, 1999; Ritchie \& Brindley, 2007; Sundram et al., 2011). For this reason, SC partners who participate in RR sharing will have a competitive advantage, thereby improving SC performance in the long run (Towill, 2005). Thus, the following hypothesis has been created:

H2: Risk and reward sharing has a positive impact on SC performance.

\subsubsection{Level of Information Sharing (IS)}

IS refers to the level or extent to which critical and proprietary information is shared, or communicated, with partners of the supply chain, particularly in regards to information about the market, product, or customer (Li et al., 2006; Mentzer et al., 2001). Improving SC performance depends on both the quantity and quality of the information being shared. Specifically, making this information accessible and visible to the other parties of the supply chain facilitates more efficient and more accurate business decisions, which then can translate into a competitive benefit (Moberg, Cutler, Gross, \& Speh, 2002). In this way, IS contributes to reducing the total cost of the supply chain in how it relates to performance (Gavirneni, 2006) by terminating the effect of fluctuation in customer demand (Fiala, 2005). According to (Stein \& Sweat, 1998), when SC partners exchange information regularly, they can better identify the needs of the end customer, thereby resulting in a more efficient response to market change. Thus, the following hypothesis has been created:

H3: Information sharing has a positive impact on SC performance. 


\subsubsection{Information Quality (IQ)}

IQ describes the extent to which there is accuracy, timeliness, satisfaction, and credibility in regards to the exchange and flow of information (Li et al., 2006). Information sharing is important, but its significance on SCM depends on what information is being shared, when it is being shared, and how it is being shared, as well as with whom (Holmberg, 2000). Forslund \& Jonsson (2007) have indicated that various IQ deficiencies affect the accuracy and, thus, practicality of the prediction, as well as its ability to influence SC operation. Thus, the quality of the information affects the ability of practitioners to make effective business choices (Soliman, Janz, Raisinghani, \& Meade, 2005). This means that supply chain partners are responsible for the accuracy, timeliness, and overall adequacy of the flow of information in order to positively affect SC performance. Thus, the following hypothesis has been created:

H4: Quality of information sharing has a positive impact on SC performance.

\subsubsection{Supplier Relationship Management (SRM)}

SRM is defined as the longstanding relationship with which to leverage the strategic and operational capabilities of each participating firm so that all involved can enjoy significant benefits (Li et al., 2006; Li et al., 2005). That is to say, a true supplier partnership encourages mutual planning and problem-solving efforts (Gunasekaran, Patel, \& Tirtiroglu, 2001). Gandhi et al. (2017) have investigated the impact of supplier management on SC performance; their finding is that successful supplier management is directly correlated to a higher level of SCP. To achieve effective SRM, though, coordination is required between the supply chain partners. With this effective coordination, there can then be successful SRM, thereby ensuring a seamless flow between the supplier and the firm; this will, in turn, allow for the right product being available at the right time, resulting in the enhancement of SC performance (Sundram et al., 2011). Thus, the following hypothesis has been created:

H5: Supplier relationship management has a positive impact on SC performance.

\subsubsection{Customer Relationship Management (CRM)}

CRM refers to the ability to create a longstanding relationship with customers; this includes treatment of customer complaints and the ability to, overall, boost customer satisfaction (Tan, Kannan, Handfield, \& Ghosh, 1999). The ability of a firm to develop effective CRM will assist the firm in providing value to the customer, thereby gaining the customer's long-term loyalty through improved customer satisfaction (Cox, 2004). The ability to maintain good CR and attain valid and useful customer feedback is an important dimension of SCMP. Additionally, a firm's ability to respond to the needs of a customer by meeting demand through the creation of new products enhances a firm's ability to perform better (Gawankar, Kamble, \& Verma, 2013a). If a solid customer relationship is in place, then a firm has the ability to offer the right product and services to the customer (Sundram et al., 2011). Thus, CRM enables the ability of a firm to re- 
tain customers (Ranjan, 2010), and this, in turn, helps improve a firm's performance. Thus, the following hypothesis has been created:

H6: Customer relationship management has a positive impact on SC performance.

\subsubsection{Supply Chain Performance (SC Performance)}

SC performance refers to the extent to which the supply chain meets a customer's needs in terms of the products and services available and time of delivery of these products and services (Beamon, 1998; Li et al., 2002; Tarafdar \& Qrunfleh, 2017). SC performance is based on factors used to determine the efficiency and effectiveness of an existing supply chain system. Parameters were determined in the literature review which can judge the efficiency and effectiveness of the supply chain; such parameters included customer satisfaction, sales, and profit. In this current study, however, we have used other common SCP factors addressed in the literature: forecasting and material accuracy, on-time delivery capability, delivery reliability and consistency, precise supply chain cost knowledge and control, fast customer response, coordinated product flow direct from supplier to store, inventory management, rationalization, and responsiveness to changing requirements (Gandhi et al., 2017; Qrunfleh \& Tarafdar, 2014; Tracey, Vonderembse, \& Lim, 1999). Thus, the following hypothesis has been created:

H7: Supply chain performance has a positive impact on a firm's financial performance.

\subsubsection{Firm Financial Performance (FFP)}

Performance measures reflect how the firm is performing about its objectives, mission, and values. These measures include conventional measures of performance for a business unit. From the literature, it has been shown that common FFP measures include return on asset, market share, return on investment, net profit, growth in net profit, sales, growth in sales, productivity ratio, total cycle time, total cash flow time, cost savings, inventory turns, net income before taxes, gross margin, quality performance, inventory management performance, and financial liquidity. There are non-financial measures as well, including overall competitive position, the present value of a firm, innovation performance, market share, performance, and quality improvement. However, the FFP in this current study was measured using indicators of financial performance like profit, revenues, and return on investment (Beamon, 1998; Chen \& Paulraj, 2004; Gawankar et al., 2013b).

\section{Research Design and Methodology}

The main purpose of this study was to investigate the relationship between different SCMPs and SC performance and the relationship between SC performance and FFP. The primary study instrument used for this research was a validated questionnaire. A summary of the survey questions is shown with the summary of statistics in Table 2 . 
Table 2. Survey questions and descriptive statistics.

\begin{tabular}{|c|c|c|c|}
\hline Item code & Survey question & Mean & Std. Deviation \\
\hline PLN1 & Our firm uses historical data in the development of forecasting & 4.97 & 0.984 \\
\hline PLN2 & Our firm implements "What-if" analysis for supply/demand & 4.97 & 0.897 \\
\hline PLN3 & A change in the demand information instantaneously "re-configures" the production and supply plans & 5.07 & 0.974 \\
\hline PLN4 & In our firm, assigns a supply chain planning team & 4.98 & 0.88 \\
\hline PLN5 & In our firm, different functions involved in the supply chain planning process & 5.09 & 0.954 \\
\hline RRS1 & Supply chain members share risks and rewards & 4.64 & 0.801 \\
\hline RRS2 & Supply chain members share research and development costs and results & 4.76 & 0.71 \\
\hline RRS3 & Supply chain members help each other with financial capital investment & 4.86 & 0.959 \\
\hline LIS1 & Our firm and our suppliers exchange information that helps the establishment of business planning & 5.02 & 0.936 \\
\hline LIS2 & Our firm shares our business units' proprietary information with suppliers & 5.04 & 0.879 \\
\hline LIS3 & Our suppliers share business knowledge of core business processes with us & 5.04 & 0.911 \\
\hline QIS1 & Information exchange between an organization and its trading partners is timely & 4.97 & 0.894 \\
\hline QIS2 & Information exchange between an organization and its trading partners is accurate & 4.99 & 0.939 \\
\hline QIS3 & Information exchange between an organization and its trading partners is complete & 4.91 & 0.772 \\
\hline QIS4 & Information exchange between an organization and its trading partners is adequate & 4.88 & 0.734 \\
\hline QIS5 & Information exchange between an organization and its trading partners is reliable & 4.85 & 0.846 \\
\hline SRM1 & Our firm relies on a few high-quality suppliers & 4.85 & 0.812 \\
\hline SRM2 & Our firm has helped our suppliers to improve their product quality & 4.93 & 0.811 \\
\hline SRM3 & Our firm has a thorough supplier rating system based on which business is given to the suppliers & 4.98 & 0.874 \\
\hline CRM1 & Our firm frequently evaluates the formal and informal complaints of our customers & 4.97 & 0.936 \\
\hline CRM2 & $\begin{array}{l}\text { Our firm frequently measures and evaluates customer satisfaction and uses it to determine their } \\
\text { requirements }\end{array}$ & 5.12 & 0.82 \\
\hline CRM3 & Our firm responds to customers' evolving needs and wants & 4.85 & 0.891 \\
\hline CRM4 & Customer focus is reflected in our business planning & 5.04 & 0.846 \\
\hline CRM5 & Our firm actively seek ways to improve the primary product/service to achieve satisfaction & 5.12 & 0.988 \\
\hline SCP1 & Our forecasting and material planning accuracy is high most of the time & 4.98 & 0.939 \\
\hline SCP2 & Our firm has on-time delivery capability & 4.99 & 0.909 \\
\hline SCP3 & Our key suppliers ensure delivery, reliability, and consistency & 4.96 & 0.882 \\
\hline SCP4 & Our firm has precise supply chain cost knowledge and control & 4.87 & 0.871 \\
\hline SCP5 & Our firm has a fast customer response time & 5.06 & 0.932 \\
\hline SCP6 & Our firm has rigorous inventory management and rationalization & 5.04 & 0.925 \\
\hline FFP1 & $\begin{array}{l}\text { Please evaluate your company's return on an investment relative to your major competitors } \\
(1=\text { much worse; } 6=\text { much better). }\end{array}$ & 4.78 & 0.829 \\
\hline FFP2 & Please evaluate your company's revenue relative to your major competitors & 4.83 & 0.883 \\
\hline FFP3 & Please evaluate your company's profit relative to your major competitors & 4.91 & 0.854 \\
\hline
\end{tabular}




\subsection{Data Collection}

A total of 3500 surveys were mailed, and the response rate was approximately $5.6 \%$. The data analysis is based on the 196 usable questionnaires. Additionally, a series of interviews were conducted with different supply chain managers to ascertain information regarding the problems that supply chains face, as well as to learn which practices are most important for the improvement of supply chain performance in the Kingdom of Saudi Arabia.

\subsection{The Sample List}

The sample firms for the study were randomly selected from the database of the three main Commercial Chambers of Saudi Arabia (Riyadh, Sharqia, and Jeddah), which lists different industries. The targeted respondents were senior executives (i.e., GM, CEO, plant manager, SC manager, purchasing manager). Most respondents (24\%) were general managers, and more than $39 \%$ of the firms represented the basic materials industry. In terms of number of employees, almost $40 \%$ of the firms were in the category of $101-200$ employees. Almost $65 \%$ of the respondents had been in their current firm for at least five years. Over $88 \%$ of the sample had earned a bachelor's degree. Male respondents comprised approximately $92 \%$ of the sample. The details of the demographic data are shown in Table 3.

\subsection{Measurement Scales}

Survey questions and descriptive statistics for each survey statement are presented in Table 2. Each statement required responses based on a 6-point Likert scale $(1=$ Strongly disagree to $6=$ Strongly agree). Questions PLN1 to PLN5 were used to measure SC planning practices; questions RRS1 to RRS3 were used to measure RR sharing practices; questions IS1 to IS3 were used to measure the level of information sharing between supply chain partners; questions IQ1 to IQ5 were used to measure the quality of information being shared between supply chain members; questions SRM1 to SRM3 were used to measure supplier relationship management practices; and questions CRM1 to CRM5 were used to measure customer relationship management practices. SC performance was measured by questions SCP1 to SCP6. Questions FFP1 to FFP3 were used to measure the FFP as compared to its competitor companies $(1=$ much worse; $6=$ much better).

\subsubsection{Validity and Reliability of the Instrument}

The validation process for the survey instrument included two steps: content validity and reliability. The literature review and in-depth interviews conducted with business executives and researchers established the basis of content validity, showing that the items measured what they were purported to measure. Reliability was measured by Cronbach's alpha. The lower limit of 0.7 is considered acceptable for established scales (Nunnally, 1994). Cronbach's coefficient alpha is shown in Table 3. 
Table 3. Respondent characteristics.

\begin{tabular}{|c|c|c|c|}
\hline Classification & Sub-Classification & Frequency & Percentage \\
\hline \multirow{2}{*}{ Age } & Male & 181 & $92 \%$ \\
\hline & Female & 15 & $8 \%$ \\
\hline \multirow{4}{*}{ Education } & $\mathrm{PhD}$ & 5 & $2.6 \%$ \\
\hline & Master's & 13 & $6.6 \%$ \\
\hline & Bachelor's & 174 & $88.8 \%$ \\
\hline & Diploma (2 years) after high school & 4 & $2 \%$ \\
\hline \multirow{6}{*}{ Position level } & CEO & 37 & $18.9 \%$ \\
\hline & GM & 47 & $24 \%$ \\
\hline & SC Manager & 33 & $16.8 \%$ \\
\hline & Operation Manager & 35 & $17.9 \%$ \\
\hline & Factory Manager & 5 & $2 \%$ \\
\hline & Purchasing Manager & 6 & $20.4 \%$ \\
\hline \multirow{5}{*}{$\begin{array}{l}\text { Length of service in the } \\
\text { current firm }\end{array}$} & Less than 5 years & 69 & $35.2 \%$ \\
\hline & $5-10$ & 37 & $18.9 \%$ \\
\hline & $11-15$ & 43 & $21.9 \%$ \\
\hline & $16-20$ & 36 & $18.4 \%$ \\
\hline & More than 20 & 11 & $5.6 \%$ \\
\hline \multirow{4}{*}{ No of Employees } & $5-100$ & 37 & $18.9 \%$ \\
\hline & $101-200$ & 78 & $39.8 \%$ \\
\hline & $201-500$ & 11 & $5.6 \%$ \\
\hline & More than 500 & 70 & $35.7 \%$ \\
\hline \multirow{7}{*}{ Industry } & Energy & 7 & $3.6 \%$ \\
\hline & Retail & 67 & $34.2 \%$ \\
\hline & Health care & 5 & $2.6 \%$ \\
\hline & Petrochemical & 11 & $5.6 \%$ \\
\hline & Automotive & 7 & $3.6 \%$ \\
\hline & Basic materials & 77 & $39.3 \%$ \\
\hline & Food and beverage & 22 & $11.2 \%$ \\
\hline
\end{tabular}

\subsubsection{The Results of the Measurement Scales}

The results of the measurement scales are shown in Table 2. All scales have Cronbach's alpha value of 0.7 or higher. Table 2 also reports the mean value and standard deviation of each item in the survey.

\subsubsection{Correlation Analysis}

The next step was to conduct a correlation analysis between variables. Table 4 presents the bivariate correlation between SCMPs, SC performance, and FFP. As 
Table 4 shows, each construct shares a greater variance with its own measures than with any other construct. This reveals that each construct is more closely related to its own measures than to those of other constructs, thereby confirming the discriminant validity (Fornell \& Bookstein, 1982).

\section{Results}

Table 2 shows that the mean score of SC planning, IS, and CRM is much higher than other SCMPs, indicating significant use of those practices. At the same time, RRS and IQ mean scores were the lowest, indicating a lack of use of those practices.

We used multiple regression to test the relationship and the statistical significance of the parameters using a t-test in the structural model (Chin, 1998). The variance explained $\left(R^{2}\right)$ and the significance of the path coefficient indicates the quality of the model (Chin, 1998). Table 5 shows the result of the model. The $R^{2}$ value was 0.929 , indicating that the model explains a good amount of the variance in SC performance.

\section{Findings Related to Hypothesis and Discussion}

In this section, we discuss the results shown in Table 6. The results are statistically significant at the 0.001 level for $\mathrm{H} 1, \mathrm{H} 3, \mathrm{H} 5, \mathrm{H} 6$, and $\mathrm{H} 7$, showing strong support for those hypotheses. However, the results show that $\mathrm{H} 2$ and $\mathrm{H} 4$ are not supported.

Table 4. Correlation and reliability.

\begin{tabular}{|c|c|c|c|c|c|c|c|c|c|c|}
\hline Construct & Reliability & No. of items & $\begin{array}{c}\text { SC } \\
\text { Planning }\end{array}$ & $\begin{array}{c}\text { R\&R } \\
\text { Sharing }\end{array}$ & IS & IQ & SRM & CRM & $\begin{array}{c}\text { SC } \\
\text { Performance }\end{array}$ & $\begin{array}{c}\text { FF } \\
\text { Performance }\end{array}$ \\
\hline SC Planning & 0.907 & 5 & 1 & & & & & & & \\
\hline R\&R Sharing & 0.741 & 3 & $0.567^{* *}$ & 1 & & & & & & \\
\hline IS & 0.812 & 3 & $0.826^{* *}$ & $0.508^{\star \star}$ & 1 & & & & & \\
\hline IQ & 0.862 & 5 & $0.796^{* *}$ & $0.552^{\star \star}$ & $0.730^{\star *}$ & 1 & & & & \\
\hline SRM & 0.873 & 3 & $0.871^{* *}$ & $0.511^{* *}$ & $0.861^{\star \star}$ & $0.785^{* *}$ & 1 & & & \\
\hline CRM & 0.905 & 5 & $0.828^{\star *}$ & $0.557^{\star \star}$ & $0.853^{\star *}$ & $0.773^{* *}$ & $0.852^{\star *}$ & 1 & & \\
\hline SC Performance & 0.939 & 6 & $0.916^{* *}$ & $0.534^{\star \star}$ & $0.896^{\star *}$ & $0.783^{\star *}$ & $0.915^{\star *}$ & $0.898^{* *}$ & 1 & \\
\hline FF Performance & 0.764 & 3 & $0.726^{\star \star}$ & $0.527^{\star \star}$ & $0.743^{\star \star}$ & $0.715^{\star *}$ & $0.708^{\star *}$ & $0.766^{\star *}$ & $0.767^{\star \star}$ & 1 \\
\hline
\end{tabular}

** Correlation is significant at the 0.01 level (2-tailed).

Table 5. Model fit.

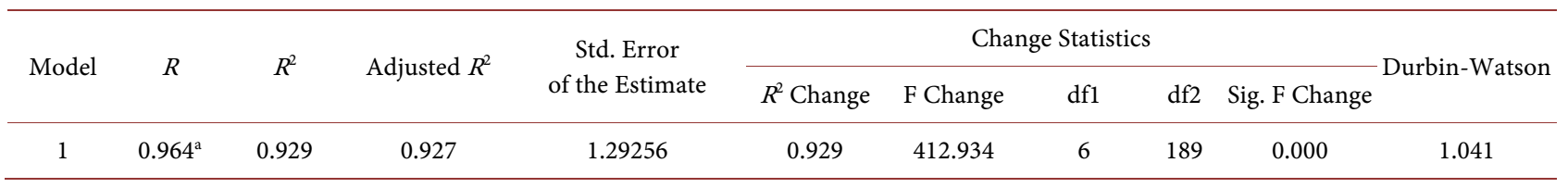

a. Predictors: (Constant), CRM, RR sharing IQ, IS, SC planning, and SRM; b. Dependent Variable: SC performance. 
Table 6. Summary of hypothesis results.

\begin{tabular}{|c|c|c|c|c|c|}
\hline \multirow{2}{*}{ Hypothesis } & \multirow{2}{*}{ Relationship } & \multirow{2}{*}{ Path Coefficient } & \multirow{2}{*}{$t$-value } & \multicolumn{2}{|c|}{ Resulting Support } \\
\hline & & & & Significant & Hypothesis supported? \\
\hline $\mathrm{H} 1$ & SC Planning $\rightarrow$ SC performance Performance & 0.365 & 8.086 & $* * *$ & Yes \\
\hline $\mathrm{H} 2$ & RR Sharing $\rightarrow$ SC Performance & -0.025 & -1.044 & 0.298 & No \\
\hline $\mathrm{H} 3$ & IS $\rightarrow$ SC Performance & 0.209 & 4.818 & $* * *$ & Yes \\
\hline $\mathrm{H} 4$ & IQ $\rightarrow$ SC Performance & -0.026 & -0.737 & 0.462 & No \\
\hline H5 & SRM $\rightarrow$ SC Performance & 0.238 & 4.887 & $* * *$ & Yes \\
\hline $\mathrm{H} 6$ & CRM $\rightarrow$ SC Performance & 0.249 & 5.652 & $* * *$ & Yes \\
\hline H7 & SC Performance $\rightarrow$ FFP & 0.767 & 16.652 & $* * *$ & Yes \\
\hline
\end{tabular}

Note: ${ }^{\star} p$-value $<0.01,{ }^{\star *} p$-value $<0.05,{ }^{* * *} p<0.001$, respectively.

We hypothesized that SC planning has a positive impact on SC performance. The results show that $\mathrm{H} 1$ is strongly supported and statistically significant, as shown by $\left(\beta 0.365={ }^{* *} ; t\right.$-value $\left.=8.086\right)$. This result provides empirical evidence for the impact of SC planning on SC performance.

We hypothesized that IS has a positive impact on SC performance. The results of the study show that $\mathrm{H} 3$ is strongly supported and statistically significant, as shown by $\left(\beta 0.209={ }^{* * *} ; t\right.$-value $\left.=4.818\right)$. Furthermore, this study shows that sharing information between SC members leads to improved SC performance. Continuous communication between firms and their suppliers leads to real-time inventory, which helps suppliers better plan their delivery schedules, thereby improving SC performance (Sundram et al., 2011).

We hypothesized that SRM has a positive impact on SC performance. The results of this study show that $\mathrm{H} 5$ is strongly supported and statistically significant, as shown by $\left(\beta 0.238={ }^{* *} ; t\right.$-value $\left.=4.887\right)$. The results of this study indicate that firms need to develop mutually beneficial relationships with suppliers and view their suppliers as partners. That is to say, firms and their suppliers need to work together in terms of planning, coordination, and forecasting in order to positively impact SC performance (Gawankar et al., 2013b).

We hypothesized that CRM has a positive impact on SC performance. The results of this study show that $\mathrm{H} 6$ is strongly supported and statistically significant, as shown by $\left(\beta 0.249={ }^{* * *} ; t\right.$-value $\left.=5.652\right)$. If a firm draws up a customer-driven objective and all members work toward achieving customer satisfaction, this will improve firm performance (Chow et al., 2008).

We hypothesized that SC performance has a positive impact on FFP. The finding of the study shows that $\mathrm{H} 7$ is strongly supported and statistically significant, as shown by $\left(\beta 0.767={ }^{* *}\right.$; $t$-value $\left.=16.652\right)$.

The findings related to $\mathrm{H} 2$ (the relationship between RR sharing and SC performance) and H4 (the relationship between IQ and SC performance) both indicate a negative relationship with SC performance, as shown in Table 6. These results disagree with Sundram et al., 2011; Zhou \& Benton Jr. (2007), whose re- 
sults showed that the quality of information has a significant positive influence on performance.

\section{Implications, Limitations, and Future Research}

This section discusses the implications of this study for practitioners. Additionally, this section presents the study's limitations and explores what opportunities exist for future research.

\subsection{Implications for Practitioners}

This study has significant implications for practitioners, giving them valuable information that can help them adopt a suitable strategy for improving their performance. This study finds that SC planning, IS, SRM, and CRM all have a positive 4 on SC performance. These findings suggest that an organization needs to keep implementing these practices to improve SC performance. At the same time, manager should particularly focus on implementing RR sharing and IQ practices. Additionally, the results of this study show that respondents do not currently apply the practice of sharing risk and rewards but that they should; the recommendation is that managers should activate this practice, especially in regard to sharing the research and development costs with other supply chain members so as to improve SC performance.

\subsection{Limitations and Future Research}

There are several limitations to this study, which could provide opportunities for future research. First, this study examined the impact of different practices-SC planning, RR sharing, IS, QIS, SRM, and CRM-on the SC performance for firms of different industries only in the Kingdom of Saudi Arabia; in the future, these effects could be studied in a specific industry, such as retail or the service industry. Second, researchers could study different moderators to find out what those moderators' impact (strengths or weaknesses) is on the relationship between SCMPs and SC performance. Third, this study focused on firms located in the three main regions of Saudi Arabia; future research could include other areas as well. In addition, this research employed perceptual performance measures to measure return on investment, revenue, and profit. Future studies could use actual numbers to better quantify the benefits of this context.

\section{Conflicts of Interest}

The author declares no conflicts of interest regarding the publication of this paper.

\section{References}

Adebayo, I. T. (2012). Supply Chain Management (SCM) Practices in Nigeria Today: Impact on SCM Performance. European Journal of Business and Social Sciences, 1, 107-115.

Aviv, Y. (2001). The Effect of Collaborative Forecasting on Supply Chain Performance. 
Management Science, 47, 1311-1440. https://doi.org/10.1287/mnsc.47.10.1326.10260

Barber, K. D., Garza-Reyes, J. A., Kumar, V., \& Abdi, M. R. (2017). The Effect of Supply Chain Management Practices on Supply Chain and Manufacturing Firms' Performance. Journal of Manufacturing Technology Management, 28, 577-609. https://doi.org/10.1108/JMTM-11-2016-0154

Barros, C. P. (2006). Efficiency Measurement among Hypermarkets and Supermarkets and the Identification of the Efficiency Drivers. International Journal of Retail \& Distribution Management, 2, 135-154.

Beamon, B. M. (1998). Supply Chain Design and Analysis: Models and Methods. International Journal of Production Economics, 55, 281-294.

https://doi.org/10.1016/S0925-5273(98)00079-6

Bowersox, D. J., Closs, D. J., \& Stank, T. P. (1999). 21st Century Logistics: Making Supply Chain Integration a Reality. Lombard, IL: Council of Supply Chain Management Professionals.

Chen, I. J., \& Paulraj, A. (2004). Towards a Theory of Supply Chain Management: The Constructs and Measurements. Journal of Operations Management, 22, 119-150.

Chen, L., Peng, J., Liu, Z., \& Zhao, R. (2017). Pricing and Effort Decisions for a Supply Chain with Uncertain Information. International Journal of Production Research, 55, 264-284. https://doi.org/10.1080/00207543.2016.1204475

Chin, W. W. (1998). The Partial Least Squares Approach to Structural Equation Modeling. In G. A. Marcoulides (Ed.), Modern Methods for Business Research (pp. 295-336). Mahwah, NJ: Lawrence Erlbaum Associates.

Chong, A. Y., Chan, F. T., Ooi, K.-B., \& Sim, J.-J. (2011). Can Malaysian Firms Improve Organizational/Innovation Performance via SCM? Industrial Management \& Data Systems, 111, 410-431. https://doi.org/10.1108/02635571111118288

Chopra, S., \& Meindl, P. (2001). Supply Chain Management: Strategy. Planning and Operation, 15, 71-85.

Chow, W. S., Madu, C. N., Kuei, C.-H., Lu, M. H., Lin, C., \& Tseng, H. (2008). Supply Chain Management in the US and Taiwan: An Empirical Study. Omega, 36, 665-679. https://doi.org/10.1016/j.omega.2006.01.001

Cook, L. S., Heiser, D. R., \& Sengupta, K. (2011). The Moderating Effect of Supply Chain Role on the Relationship between Supply Chain Practices and Performance: An Empirical Analysis. International Journal of Physical Distribution \& Logistics Management, 41, 104-134. https://doi.org/10.1108/09600031111118521

Cook, R. L., \& Rogowski, R. A. (1996). Applying JIT Principles to Continuous Process Manufacturing Supply Chains. Production and Inventory Management Journal, 37, 12-17.

Cox, A. (2004). The Art of the Possible: Relationship Management in Power Regimes and Supply Chains. Supply Chain Management, 9, 346-356. https://doi.org/10.1108/13598540410560739

Croom, S., Romano, P., \& Giannakis, M. (2000). Supply Chain Management: An Analytical Framework for Critical Literature Review. European Journal of Purchasing \& Supply Management, 6, 67-83. https://doi.org/10.1016/S0969-7012(99)00030-1

de Souza Miguel, P. L., \& Brito, L. A. L. (2011). Supply Chain Management Measurement and Its Influence on Operational Performance. Journal of Operations and Supply Chain Management, 4, 56-70. https://doi.org/10.12660/joscmv4n2p56-70

Forslund, H., \& Jonsson, P. (2007). The Impact of Forecast Information Quality on Supply Chain Performance. International Journal of Operations \& Production Man- 
agement, 27, 90-107. https://doi.org/10.1108/01443570710714556

Fiala, P. (2005). Information Sharing in Supply Chains. Omega, 33, 419-423. https://doi.org/10.1016/j.omega.2004.07.006

Fornell, C., \& Bookstein, F. L. (1982). Two Structural Equation Models: LISREL and PLS Applied to Consumer Exit-Voice Theory. Journal of Marketing Research, 19, 440-452. https://doi.org/10.1177/002224378201900406

Gandhi, A. V., Shaikh, A., \& Sheorey, P. A. (2017). Impact of Supply Chain Management Practices on Firm Performance. International Journal of Retail \& Distribution Management, 45, 366-384. https://doi.org/10.1108/IJRDM-06-2015-0076

Gavirneni, S. (2006). Price fluctuations, Information Sharing, and Supply Chain Performance. European Journal of Operational Research, 174, 1651-1663. https://doi.org/10.1016/j.ejor.2005.04.037

Gawankar, S., Kamble, S. S., \& Verma, R. (2013a). Development, Measurement and Validation of Supply Chain Management Practices Scale in Indian Retail Sector. International Journal of Procurement Management, 6, 495-522.

https://doi.org/10.1504/IJPM.2013.056169

Gawankar, S., Kamble, S. S., \& Verma, R. (2013b). Effect of Supply Chain Management Practices on Supply Chain Profitability: An Empirical Investigation Using Structural Equation Modelling in Indian Retail Sector. International Journal of Services and Operations Management, 16, 145-173. https://doi.org/10.1504/IJSOM.2013.056164

Gharakhani, D., Mavi, R. K., \& Hamidi, N. (2012). Impact of Supply Chain Management Practices on Innovation and Organizational Performance in Iranian Companies. African Journal of Business Management, 6, 5939-5949.

Green, K. W., McGaughey, R., \& Casey, K. M. (2006). Does Supply Chain Management Strategy Mediate the Association between Market Orientation and Organizational Performance? Supply Chain Management, 11, 407-414.

https://doi.org/10.1108/13598540610682426

Gunasekaran, A., Patel, C., \& Tirtiroglu, E. (2001). Performance Measures and Metrics in a Supply Chain Environment. International Journal of Operations \& Production Management, 21, 71-87. https://doi.org/10.1108/01443570110358468

Hall, M. A. (1999). Correlation-Based Feature Selection for Machine Learning. PhD Thesis, Hamilton: University of Waikato.

Hodge, B., Anthony, W., \& Gale, L. (1996). Organizational Theory: A Strategic Approach. New York, NY: Prentice Hall.

Holmberg, S. (2000). A Systems Perspective on Supply Chain Measurements. International Journal of Physical Distribution \& Logistics Management, 30, 847-868. https://doi.org/10.1108/09600030010351246

Jones, C. (1998). Moving beyond ERP: Making the Missing Link. Logistics Focus, 6, 2-7.

Jüttner, U. (2005). Supply Chain Risk Management: Understanding the Business Requirements from a Practitioner Perspective. The International Journal of Logistics Management, 16, 120-141. https://doi.org/10.1108/09574090510617385

Koh, S. L., Demirbag, M., Bayraktar, E., Tatoglu, E., \& Zaim, S. (2007). The Impact of Supply Chain Management Practices on Performance of SMEs. Industrial Management \& Data Systems, 107, 103-124. https://doi.org/10.1108/02635570710719089

Krajewski, L., \& Wei, J. C. (2001). The Value of Production Schedule Integration in Supply Chains. Decision Sciences, 32, 601-634.

Kumar, A., \& Kushwaha, G. (2018). Supply Chain Management Practices and Operational Performance of Fair Price Shops in India: An Empirical Study. LogForum, 14, 8. 
https://doi.org/10.17270/J.LOG.2018.237

Lau, H. C., \& Lee, W. (2000). On a Responsive Supply Chain Information System. International Journal of Physical Distribution \& Logistics Management, 30, 598-610. https://doi.org/10.1108/09600030010346242

Lee, H. L., Padmanabhan, V., \& Whang, S. (1997). Information Distortion in a Supply Chain: The Bullwhip Effect. Management Science, 43, 546-558. https://doi.org/10.1287/mnsc.43.4.546

Li, S., Rao, S., Ragu-Nathan, T. S., \& Ragu-Nathan, B. (2002). An Empirical Investigation of Supply Chain Management Practices. Proceedings of the 33rd Annual Meeting of the Decision Science Institute, 23-25 November 2002, San Diego, 112-129.

Li, S., Ragu-Nathan, B., Ragu-Nathan, T., \& Rao, S. S. (2006). The Impact of Supply Chain Management Practices on Competitive Advantage and Organizational Performance. Omega, 34, 107-124. https://doi.org/10.1016/j.omega.2004.08.002

Li, S., Rao, S. S., Ragu-Nathan, T., \& Ragu-Nathan, B. (2005). Development and Validation of a Measurement Instrument for Studying Supply Chain Management Practices. Journal of Operations Management, 23, 618-641.

https://doi.org/10.1016/j.jom.2005.01.002

Mentzer, J. T., DeWitt, W., Keebler, J. S., Min, S., Nix, N. W., Smith, C. D., \& Zacharia, Z. G. (2001). Defining Supply Chain Management. Journal of Business Logistics, 22, 1-25. https://doi.org/10.1002/j.2158-1592.2001.tb00001.x

Min, S., \& Mentzer, J. T. (2004). Developing and Measuring Supply Chain Management Concepts. Journal of Business Logistics, 25, 63-99.

https://doi.org/10.1002/j.2158-1592.2004.tb00170.x

Moberg, C. R., Cutler, B. D., Gross, A., \& Speh, T. W. (2002). Identifying Antecedents of Information Exchange within Supply Chains. International Journal of Physical Distribution \& Logistics Management, 32, 755-770.

https://doi.org/10.1108/09600030210452431

Nunnally, J. C. (1994). Psychometric Theory 3E. New York, NY: Tata McGraw-Hill Education.

Prathiba, S. (2020). Can Supply Chain Management Practices Influence Customer Satisfaction and Loyalty? Journal of Supply Chain Management Systems, 9, 1.

Qrunfleh, S., \& Tarafdar, M. (2014). Supply Chain Information Systems Strategy: Impacts on Supply Chain Performance and Firm Performance. International Journal of Production Economics, 147, 340-350. https://doi.org/10.1016/j.ijpe.2012.09.018

Ranjan, J. (2010). Integrating Analytical Customer Relationship Management with Customer Relationship Management in Organisations. International Journal of Innovation and Learning, 8, 408-426. https://doi.org/10.1504/IJIL.2010.035750

Ritchie, B., \& Brindley, C. (2007). Supply Chain Risk Management and Performance. International Journal of Operations \& Production Management, 27, 303-322. https://doi.org/10.1108/01443570710725563

Saragih, J., Tarigan, A., Pratama, I., Wardati, J., \& Silalahi, E. F. (2020). The Impact of Total Quality Management, Supply Chain Management Practices and Operations Capability on Firm Performance. Polish Journal of Management Studies, 21, 384-397. https://doi.org/10.17512/pjms.2020.21.2.27

Shetty, V. K. (2019). Impact of Supply Chain Management Practices on Performance of Companies. Journal of Supply Chain Management Systems, 8, 3.

Soliman, K. S., Janz, B. D., Raisinghani, M. S., \& Meade, L. L. (2005). Strategic Decisions in Supply-Chain Intelligence Using Knowledge Management: An Analytic-Network- 
Process Framework. Supply Chain Management, 10, 114-121.

Stein, T., \& Sweat, J. (1998). Killer Supply Chains. Information Week, 708, 36-46.

Sukati, I., Hamid, A. B., \& Baharun, R. (2013). Testing the Effect of the Supply Chain Management Implementation on Business Performance: An Empirical Study. International Business Research, 6, 76-89. https://doi.org/10.5539/ibr.v6n1p76

Sukati, I., Hamid, A. B., Baharun, R., Yusoff, R. M., \& Anuar, M. A. (2012). The Effect of Organizational Practices on Supply Chain Agility: An Empirical Investigation on Malaysia Manufacturing Industry. Procedia-Social and Behavioral Sciences, 40, 274-281. https://doi.org/10.1016/j.sbspro.2012.03.191

Sundram, V. P. K., Ibrahim, A. R., \& Govindaraju, V. (2011). Supply Chain Management Practices in the Electronics Industry in Malaysia: Consequences for Supply Chain Performance. Benchmarking, 18, 834-855. https://doi.org/10.1108/14635771111180725

Tan, K.-C., Kannan, V. R., \& Handfield, R. B. (1998). Supply Chain Management: Supplier Performance and Firm Performance. International Journal of Purchasing \& Materials Management, $34,3$.

Tan, K. C., Kannan, V. R., Handfield, R. B., \& Ghosh, S. (1999). Supply Chain Management: An Empirical Study of Its Impact on Performance. International Journal of Operations \& Production Management, 19, 1034-1052.

https://doi.org/10.1108/01443579910287064

Tarafdar, M., \& Qrunfleh, S. (2017). Agile Supply Chain Strategy and Supply Chain Performance: Complementary Roles of Supply Chain Practices and Information Systems Capability for Agility. International Journal of Production Research, 55, 925-938. https://doi.org/10.1080/00207543.2016.1203079

Teller, C., Kotzab, H., Grant, D. B., \& Holweg, C. (2016). The Importance of Key Supplier Relationship Management in Supply Chains. International Journal of Retail \& Distribution Management, 44, 109-123. https://doi.org/10.1108/IJRDM-05-2015-0072

Towill, D. R. (2005). The Impact of Business Policy on Bullwhip Induced Risk in Supply Chain Management. International Journal of Physical Distribution \& Logistics Management, 35, 555-575. https://doi.org/10.1108/09600030510623339

Tracey, M., Vonderembse, M. A., \& Lim, J.-S. (1999). Manufacturing Technology and Strategy Formulation: Keys to Enhancing Competitiveness and Improving Performance. Journal of Operations Management, 17, 411-428. https://doi.org/10.1016/S0272-6963(98)00045-X

Womack, J. P., Jones, D. T., \& Roos, D. (1990). The Machine That Changed the World (pp. 273-287). New York, NY: Rawson Associates.

Xiao, Q., Chen, L., Xie, M., \& Wang, C. (2020). Optimal Contract Design in Sustainable Supply Chain: Interactive Impacts of Fairness Concern and Overconfidence. Journal of the Operational Research Society, 1-20. https://doi.org/10.1080/01605682.2020.1727784

Yanya, M., \& Mahamat, N. (2020). The Impact of Supply Chain Management Practices on Competitive Advantages: Moderation Role of Total Quality Management. Polish Journal of Management Studies, 21, 419-431. https://doi.org/10.17512/pjms.2020.21.1.31

Zhou, H., \& Benton Jr., W. (2007). Supply Chain Practice and Information Sharing. Journal of Operations Management, 25, 1348-1365.

https://doi.org/10.1016/j.jom.2007.01.009 